\title{
Investigation of Photovoltaic Assisted Misting System Application for Arbor Refreshment
}

\author{
Hikmet Esen ${ }^{1}$ and Omer Tuna ${ }^{2}$ \\ ${ }^{1}$ Department of Energy Systems Engineering, Faculty of Technology, Firat University, 23119 Elazig, Turkey \\ ${ }^{2}$ Vocational School, Muş Alparslan University, 49100 Muş, Turkey \\ Correspondence should be addressed to Hikmet Esen; esenhikmet@gmail.com
}

Received 7 December 2014; Accepted 5 March 2015

Academic Editor: Leonardo Palmisano

Copyright ( $2015 \mathrm{H}$. Esen and O. Tuna. This is an open access article distributed under the Creative Commons Attribution License, which permits unrestricted use, distribution, and reproduction in any medium, provided the original work is properly cited.

\begin{abstract}
In this study, for the first time in the literature, solar assisted cooler with misting system established on an arbor with an area of $24 \mathrm{~m}^{2}$ and georeferenced in Elazig $\left(38.6775^{\circ} \mathrm{N}, 39.1707^{\circ} \mathrm{E}\right)$, Turkey, is presented. Here, we present a system that reduces interior temperature of the arbor while increasing humidity. Also, the system generates required electricity with a solar photovoltaic module to power pressurized water pump through an inverter and stores it in a battery for use when there is no sunlight. The model of the photovoltaic module was implemented using a Matlab program. As a result of being an uncomplicated system, return on investment for the system is 3.7 years.
\end{abstract}

\section{Introduction}

The cooling techniques can be categorized into several forms, including pad and fan, misting, and fog. Each cooling technique utilizes the evaporative cooling (EC) process to decrease air temperature, as well as fan ventilation for exchanging the moist air with dry outside air. The impression of each system is highly dependent on the ambient airwater vapor properties. Low air humidity will increase the cooling capacity of the evaporative system, while higher humidity will decrease cooling. In addition, cooling effect is dependent on the nozzle design and system operating pressure, which directly influences evaporation of the droplet due to the droplet size delivered from the nozzle. Water quality is important for the long term effectiveness and required maintenance of EC systems [1].

Providing thermal comfort conditions, the comparison of the economic and environmental aspects of evaporative and vapor compression cooling systems with the same capacity shows that $\mathrm{EC}$ systems have less operating cost and in terms of equivalent $\mathrm{CO}_{2}$ emissions are more environmental compared to vapor compression cooling systems.

The EC system includes direct EC type, indirect EC type, two-stage EC or indirect direct EC, and hybrid EC type. Different air condition should employ different EC type. Air in contact with water directly is the feature of direct EC type (misting) [2].

Recently, the direct and indirect evaporative cooling (EC) system has attracted more and more attention due to its superiority of high energy efficiency and environmental friendliness [3-17]. Wong and Chong [18] examined the difference in thermal comfort levels provided by the misting fan system as well as the possible increase in biological pollutants due to the increase in relative humidity brought about by the generation of mists. Katsoulas et al. [19] investigated effect of misting on transpiration and conductance of a greenhouse rose canopy. Dombrovsky et al. [20] developed a model for the hemispherical transmittance of direct and scattered solar radiation from a cloudless atmosphere by a mist layer of water droplets in order to investigate the potential of water misting systems to serve as a protection from solar irradiation with particular emphasis on harmful UV radiation. Sethi and Sharma [21] reviewed the available international cooling technologies for agricultural greenhouses and discussed the representative applications of each technology. Burger [22] examined the intermittent mist control via solar cells. Hourly data were obtained from UC Davis California Irrigation Management and Information System station for comparisons between Weather Watcher responses and evapotranspiration or 1 solar 
radiation. Zhang et al. [23] have examined continual- and intermittent-spray cooling heat transfer experiments on a flat surface to study the effects of the spray cycle, duty ratio, and spray time. The results showed that an optimal spray cycle and optimal duty ratio make more efficient use of the coolant in intermittent-spray cooling. Atieh and Al Shariff [14] demonstrated for the first time to our knowledge a misting system that is powered by solar energy. The system was used to cool down an open area in Medina, Saudi Arabia. The ambient and surrounding temperatures were measured and compared for different timing signals that were applied to the misting system. The used solar panel performance was evaluated for different loads and tilting settings. The return on investment for the misting system was found to be about two years and a half. Eicker et al. [24] have examined economic evaluation of solar thermal and photovoltaic cooling systems through simulation in different climatic conditions: an analysis in three different cities in Europe. Ban-Weiss et al. [25] have examined electricity production and cooling energy savings from installation of a building-integrated photovoltaic roof on an office building.

Since air conditioning systems have been introduced, they became part of daily life in many areas. However, air conditioning systems are relatively expensive (large portion of the electrical bill in hot weather regions is contributed to the energy consumed by the air conditioners), and they are not environmentally friendly. In addition to that, they are inefficient when used in outdoor and open areas such as arbor, streets, and parks. Thus new technologies become necessary to develop an efficient, low cost, environmentally friendly system that is capable of reducing the temperature using low cost components that are easy to run and maintain and flexible to be utilized [14].

In this study, solar assisted cooling system is implemented in an arbor of a site in Elazig. Two solar panels, each of which has a power of $150 \mathrm{~W}$, are used to power up the misting system. The temperature distribution of the arbor area was investigated by thermal camera images. Modeling of the solar cell used in the study is also conducted. This system is environmentally friendly, inexpensive, and healthy. If any cooling system is aimed at being applicable, it must be suitable by being economically feasible. Therefore return on investment of the proposed system is evaluated lastly.

\section{Experimental Methodology and System}

2.1. Concept and Advantages of Water Misting System. Water misting systems work by forcing water via a high pressure pump and tubing through a brass and stainless steel mist nozzle that has an orifice of about 5 micrometres, thereby producing a microfine mist. The water droplets that create the mist are so small that they instantly flash-evaporate. Flash evaporation can reduce the surrounding air temperature by as much as $35^{\circ} \mathrm{F}\left(20^{\circ} \mathrm{C}\right)$ in just seconds. For Patio systems, it is ideal to mount the mist line approximately 8 to 10 feet (2.4 to $3.0 \mathrm{~m}$ ) above the ground for optimum cooling. Misting is used for applications such as flowerbeds, pets, livestock, kennels, insect control, odor control, zoos, veterinary clinics, cooling of produce, and greenhouses [2].

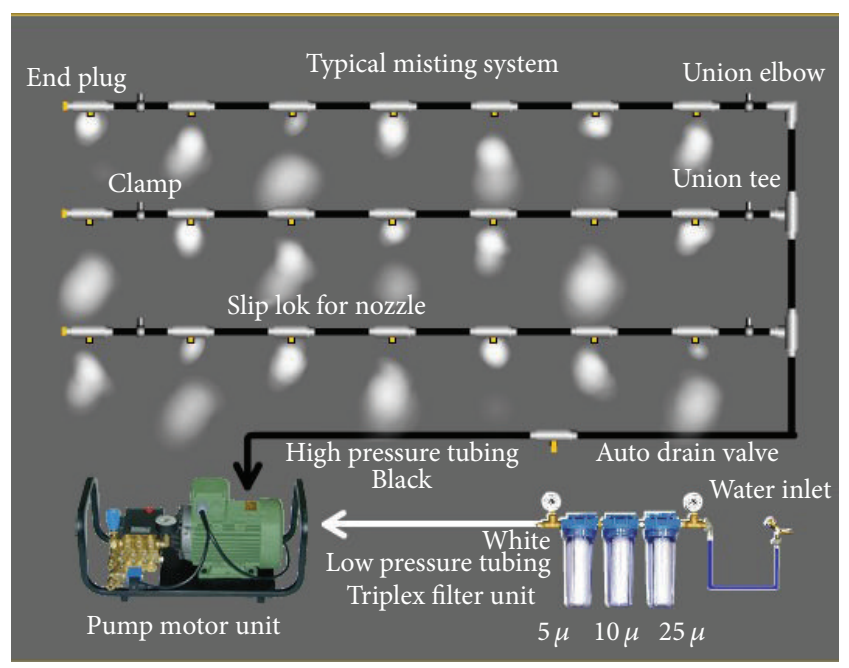

FIGURE 1: Typical representation of misting systems.

The technology used is direct EC which is efficient and productive. Misting systems are also used because the mist that is produced is so fine that there is no chance of the surrounding area becoming wet. The effect of this system compares to that of standing in middle of a fog. One remains cooler but does not become wet. A person can only become wet from the system if they stand $15.24 \mathrm{~cm}$ away from the water nozzle. The water produced from this system is also hygienic. This is because the water is filtered of impurities before it is released through the nozzles. It is also economical because it uses an average of four to eight liters per hour. There are also many outstanding features and benefits that water mist system offers which are [26]

(i) being suitable for a wide range of outdoor applications,

(ii) requiring small space and being very light,

(iii) being environmentally friendly,

(iv) being nontoxic,

(v) having highly efficient heat suppression capability,

(vi) using limited quantity of water,

(vii) being cost-effective compared to other heat reducing equipment like air conditions,

(viii) driving away many insects like mosquitoes, flies, and wasps from the area,

(ix) cleaning the surrounding area from dust and other common pollutants.

The appearance of typical misting system during the study is shown in Figure 1.

2.2. Weather in Elazig. The mean sunshine duration and outside air temperature which is higher than other months are available in July for Elazig. Relative humidity is lowest in this month. For the province of Elazig meteorological values are given in Table 1. 
TABLE 1: The average values over many years for Elazig city (1960-2012) [27].

\begin{tabular}{|c|c|c|c|c|c|c|c|c|c|c|c|c|}
\hline \multirow{2}{*}{$\begin{array}{l}\text { Meteorological } \\
\text { factors }\end{array}$} & \multicolumn{12}{|c|}{ Months } \\
\hline & Jan. & Feb. & Mar. & Apr. & May. & Jun. & Jul. & Aug. & Sep. & Oct. & Nov. & Dec. \\
\hline I & -0.8 & 0.5 & 5.8 & 11.9 & 17.2 & 22.9 & 27.3 & 26.8 & 21.6 & 14.6 & 7.1 & 1.9 \\
\hline II & 2.9 & 4.9 & 11.1 & 17.7 & 23.6 & 29.6 & 34.3 & 34.1 & 29.4 & 21.7 & 12.6 & 5.6 \\
\hline III & -3.9 & -3.1 & 1.0 & 6.4 & 10.7 & 15.2 & 19.3 & 19.0 & 14.3 & 9.0 & 3.0 & -1.1 \\
\hline IV & 2.4 & 3.4 & 5.2 & 6.5 & 9.1 & 11.4 & 12.2 & 11.4 & 9.5 & 7.1 & 4.4 & 2.3 \\
\hline V & 11.9 & 11.9 & 12.2 & 12.7 & 10.6 & 4.3 & 1.1 & 0.8 & 2.2 & 7.2 & 9.1 & 11.7 \\
\hline VI & 75 & 72 & 64 & 56 & 49 & 36 & 30 & 30 & 35 & 51 & 69 & 76 \\
\hline
\end{tabular}

I: the average temperature $\left({ }^{\circ} \mathrm{C}\right)$, II: the average high temperature $\left({ }^{\circ} \mathrm{C}\right)$, III: the average minimum temperature $\left({ }^{\circ} \mathrm{C}\right)$, IV: average sunshine hours $(\mathrm{h})$, V: average number of rainy days (day), and VI: average relative humidity (\%).

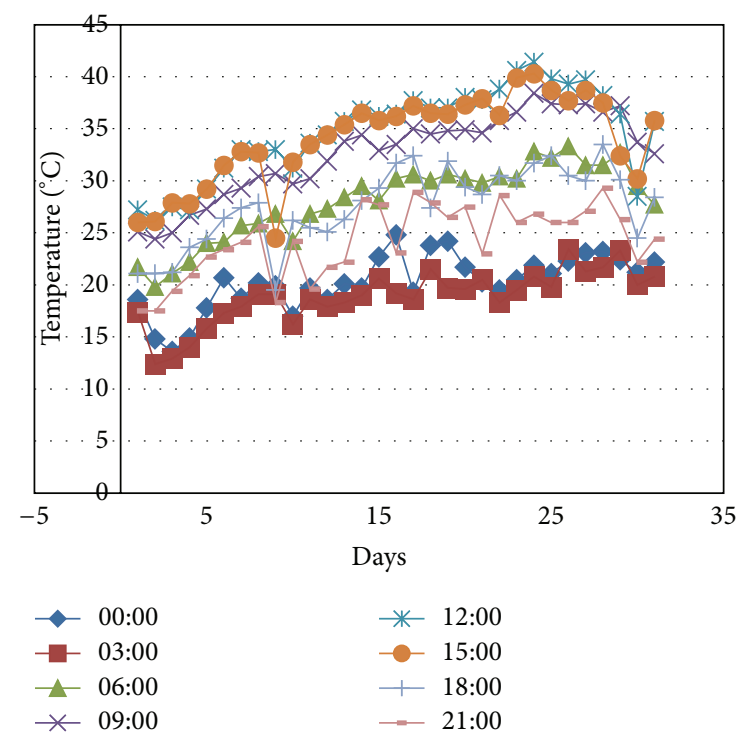

FIGURE 2: Hourly average outdoor air temperatures in the month of July.

For a period of 3 hours of Elazig outside temperature changes are given in Figure 2 for the month of July. The solar radiation $\left(\mathrm{W} / \mathrm{m}^{2}\right)$ values obtained for 10 days with solarimeter are shown in Figure 3.

The data for the other years was also reviewed and similar conclusions were achieved. These results provide great evidence that the misting system is well suited for operation in Elazig, Turkey.

2.3. Solar Energy Subsystem and Its Modeling. It will be useful to analyze PV panel performance before analyzing general performance of the system. Therefore, characteristics of solar panel are considered under a separated heading in this study. A PV panel consists of generator solar cells, junctions, protector parts, and secondary elements. Solar cells consist of $p-n$ junctions that are aggregated on a thin silicon circuit sheet or on a semiconductor layer.

$I-V$ outcome characteristics of a solar panel in the dark are similar to exponential characteristics of a diode. When solar energy (photons) arrives in solar cell with an amount

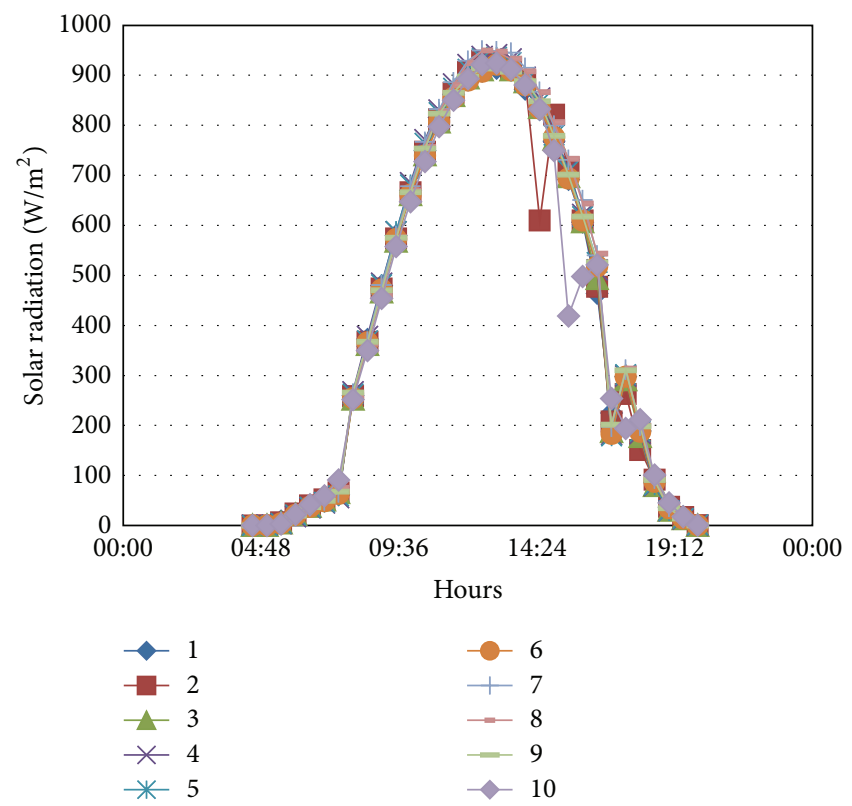

FIGURE 3: The solar radiation values obtained for 10 days in the month of July.

of energy greater than band gap energy of the semiconductor, collision occurs and then electron pair arises. These carriers are swept to a separated area under the influence of interior electric field of $p-n$ junctions and create a current proportional to incident radiation. This current flows to external circuit when short circuit occurs in the panel cell and it is directed to interior parallel circuit by $p-n$ junction diode when the circuit is open. Thus, characteristics of this diode shape the open circuit characteristics of the panel cell. Therefore, the simplest solar cell equivalent circuit is a parallel current source with the diode. Output acquired from current source is directly proportional to radiation on the panel cell. Solar cell is not an active element in dark. It performs as a diode. It does not generate current or voltage. However, if it is connected to an external source, it generates a current named as "diode current" or "dark current" [28-33].

Diode determines the $I-V$ characteristics of the cell. In order to achieve the best chart curve match-up, the diode ideality factor and a single parallel diode were used. This 


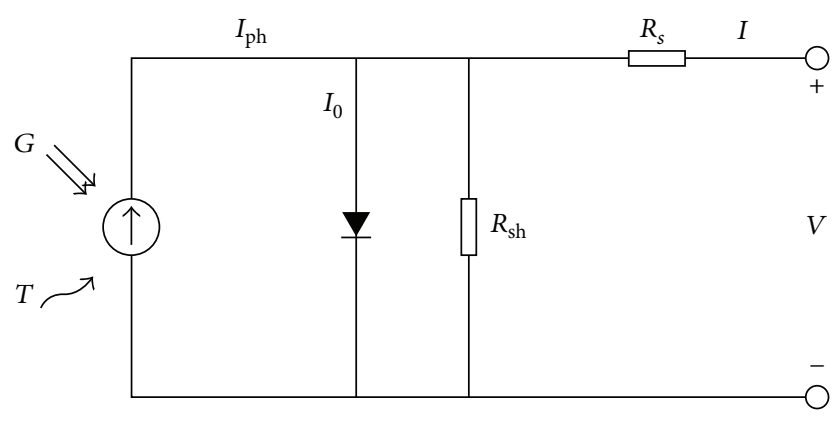

FIgURE 4: Solar cell circuit diagram. $I_{\mathrm{ph}}$ : photocurrent, $I_{0}$ : diode saturation current, $R_{s}$ : serial resistance, $R_{\mathrm{sh}}$ : shunt resistance, $T$ : ambient temperature, $G$ : ambient irradiance, and $V$ : output voltage.

model is the simplified version of two-diode model by Gow and Manning [34]. Solar cell circuit diagram is shown in Figure 4.

$I_{0}$ and $I_{\mathrm{ph}}$ depend on temperature. $R_{s}$ is included in the circuit in order to explain the description of maximum power point and open circuit voltage better. $R_{s}$ refers to interior losses caused by flow of the current. $R_{\mathrm{sh}}$ is parallel with the diode. $R_{\mathrm{sh}}$ is usually negligible and is not shown in the equivalent circuit. $R_{s}=R_{\mathrm{sh}}=0$ in the ideal panel cell [34].

$I-V$ characteristics of a solar panel can be calculated by the equations given. Middle level complexity model was used in this study. Consider

$$
\begin{gathered}
I_{\mathrm{ph}}=I_{d}+I, \\
I_{d}=I_{0}\left(e^{q\left(V+I R_{s}\right) / n k T}-1\right), \\
I=I_{\mathrm{ph}}-I_{0}\left(e^{q\left(V+I R_{s}\right) / n k T}-1\right),
\end{gathered}
$$

where $q$ is elementary charge $\left(1.602 \times 10^{-19} \mathrm{C}\right), k$ is Boltzmann constant $\left(1.381 \times 10^{-23} \mathrm{~J} / \mathrm{K}\right)$, and $n$ is diode ideality factor; it depends on the PV technology as it is shown in Table 2.

Equations (2), (3), and (4) are not enough to draw the $I-V$ curve: $I_{\mathrm{ph}}, V_{\mathrm{oc}}$, and $I_{0}$ are required to complete the model. Consider

$$
\begin{gathered}
I_{\mathrm{ph}}=I_{\mathrm{ph}}\left\langle T_{\text {ref }}\right\rangle+K_{0}\left(T-T_{\text {ref }}\right), \\
I_{\mathrm{ph}}\left\langle T_{\text {ref }}\right\rangle=I_{\mathrm{sc}}\left\langle T_{\text {ref }}\right\rangle \frac{G}{G_{\text {ref }}}, \\
I_{0}\left\langle T_{\text {ref }}\right\rangle=\frac{I_{\mathrm{sc}}\left\langle T_{\text {ref }}\right\rangle}{\left(e^{\left.q V_{\mathrm{oc}}\left\langle T_{\text {ref }}\right\rangle / n k T_{\text {ref }}-1\right)},\right.} \\
I_{0}=I_{0}\left\langle T_{\text {ref }}\right\rangle\left(\frac{T}{T_{\text {ref }}}\right)^{3 / n} e^{q V_{g}\left(T_{\text {ref }}\right) / n k\left(1 / T-1 / T_{\text {ref }}\right)},
\end{gathered}
$$

where ref identifies the standard test conditions $\left(T_{\text {ref }}=25^{\circ} \mathrm{C}\right.$, $\left.G_{\text {ref }}=1000 \mathrm{~W} / \mathrm{m}^{2}\right), K_{0}$ is temperature coefficient of the current, $I_{\mathrm{sc}}$ is short circuit current, and $V_{\mathrm{oc}}$ is open circuit voltage.
TABLE 2: Ideality factor of several PV types.

\begin{tabular}{lc}
\hline PV type & $n$ \\
\hline Monocrystalline silicon & 1.2 \\
Polycrystalline silicon & 1.3 \\
Cadmium telluride & 1.5 \\
Gallium arsenide & 1.3 \\
Amorphous silicon & 1.8 \\
\hline
\end{tabular}

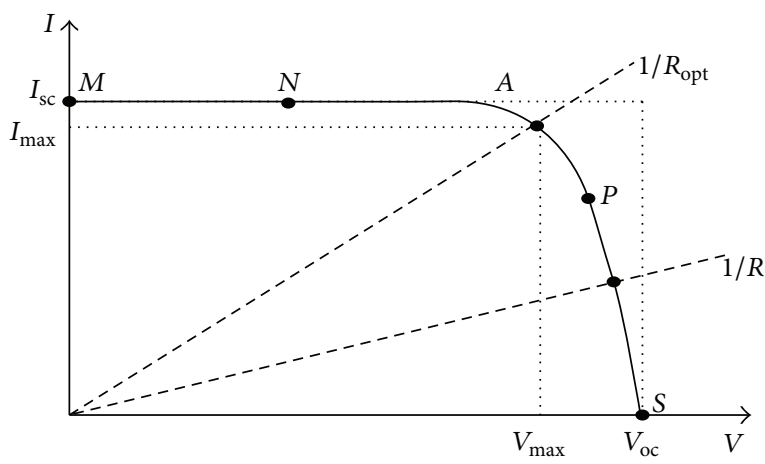

FIgURE 5: Specific $I-V$ characteristics of solar cell.

We should know the values of $R_{s}$ because it has a considerable effect on $I-V$ characteristic curves:

$$
\begin{gathered}
R_{S}=-\frac{d V}{d I_{V_{\text {oc }}}}-\frac{1}{X_{v}}, \\
X_{V}=I_{0}\left(T_{\text {ref }}\right) \frac{q}{n k T_{\text {ref }}} e^{q V_{\text {oc }}\left(T_{\text {ref }}\right) / n k T_{\text {ref }} .}
\end{gathered}
$$

Constants in these equations can be determined by analyzing $I-V$ curve charts which are measured or published in product catalogues of $\mathrm{PV}$ system producers.

Specific $I-V$ characteristics of solar cell for determined $G$ and $T$ are shown in Figure 3. Characteristic of a resistive charge is a linear line within the scope of $I / V=1 / R$. Also it should be mentioned that power delivered to this charge is based only on the resistance value [32].

However, panel has an effect on $A-B$ field of the curve chart if $R$ value is low. Cell acts as a constant current source here and it is almost equal to short circuit current. On the other hand panel has an effect on $D$-E field of the curve chart if $R$ value is high. Cell acts as a constant voltage source here and it is almost equal to open circuit voltage [29].

A real solar cell can be characterized by the following basic parameters shown in Figure 5.

Short circuit current, $I_{\mathrm{sc}}=I_{\mathrm{ph}}$ : this is the maximum current value produced by the cell. It can be produced by short circuit conditions $V=0$.

Open circuit voltage corresponds to diminished voltage in the diode ( $p-n$ junction) when it is crossed by $I_{\mathrm{ph}}$. In other words, it represents the cell voltage in dark, when the produced voltage is $I=0$.

Maximum power point is the operating point $C$ in Figure 5. This is the consumed power when the resistive charge level is maximum: $P_{\max }=V_{\max } \cdot I_{\max }$. 
TABLE 3: The main components specification and characteristics of the photovoltaic misting system studied.

\begin{tabular}{|c|c|c|c|}
\hline Systems & Element & Technical specification & Price (Euro) \\
\hline \multirow{5}{*}{ Photovoltaic system } & Solar cells (1) & Bluesun $150 \mathrm{~W}$ monocrystalline. & 465 (two units) \\
\hline & Inverter (2) & $\begin{array}{l}\text { Manufacturer: SKN-S2012; input } 220 \text { VAC, } 50 / 60 \mathrm{~Hz} \text {, } \\
30 \text { A, max, } 1 \varphi \text {; output } 220 \text { VAC, } 50 / 60 \mathrm{~Hz}, 2000 \mathrm{~W} \text {, max, } \\
1 \varphi \text {; DC input: } 12 \text { VDC; colour: black; N.W.: } 19 \mathrm{~kg} \text {, } \\
\text { G.W.: } 20 \mathrm{~kg} .\end{array}$ & 550 \\
\hline & Solar battery (3) & $\begin{array}{l}\text { VRLA GEL; } 100 \mathrm{Ah} \text {, nominal voltage: } 12 \mathrm{~V} \text {; charging } \\
\text { voltage for standby use: } 12-16 \mathrm{~V} \text {; charging current: } \\
2.25 \mathrm{~A} \text {. }\end{array}$ & 100 \\
\hline & Charge regulator (4) & Vista 15 a $12 / 24 \mathrm{~V}$ & 90 \\
\hline & Solar cell fasteners (5) & $\begin{array}{l}\text { UV protected multicontact solar cables and connectors } \\
(10 \mathrm{~m}) \text {, power cable }(15 \mathrm{~m}) \text {. }\end{array}$ & 275 \\
\hline
\end{tabular}

Manufacturer: Normist; type: RR-2; pressure: 70 bar; flow LPM: 2; engine power: $0.75 \mathrm{HP}, 0.55 \mathrm{~kW}$; voltage:

Pressure water pump (6) $220 \mathrm{~V}$; nominal ampere: $2.5 \mathrm{~A}$; nozzle diameter: $0.2 \mathrm{~mm}$; water inlet/outlet diameter: 9.525/12 $\mathrm{mm}$, noise level: $78 \mathrm{~dB}$.

Misting system

Manufacturer: Normist; hexagonal nozzle series: $0.2 \mathrm{~mm}$, number of nozzles: min 16 units, $\max 28$ units; 1000

Distribution system (7) nozzle flow value: $0.075 \mathrm{lt} / \mathrm{min}$ (at $70 \mathrm{bar}$ ), clamps, pressure switch, pump regulator, terminating line, high pressure plastic pipe, low pressure plastic pipe plastic clips, quick fittings, purge valve, T-connection, L-connection, pipe holder, filter, pressure gauge.

Maximum efficiency is the ratio between maximum power and incident light:

$$
\eta=\frac{P_{\max }}{P_{\text {in }}}=\frac{I_{\max } V_{\max }}{A G} .
$$

$A$ is the panel cell area. The efficiency of our system was calculated and the result was found as $19.92 \%$.

Fill factor is the ratio between maximum power delivered to charge and output of $I_{\mathrm{sc}}$ and $V_{\mathrm{oc}}$ :

$$
\mathrm{FF}=\frac{P_{\mathrm{max}}}{V_{\mathrm{oc}} I_{\mathrm{sc}}}=\frac{I_{\mathrm{max}} V_{\mathrm{max}}}{V_{\mathrm{oc}} I_{\mathrm{sc}}} .
$$

Fill factor is a measure of actual $I-V$ characteristics. This value is higher than 0.7 for the cells that can be accepted as good. The fill factor of the panel used in our system is 0.81 . Fill factor decreases as cell temperature increases.

While $I_{\mathrm{sc}}$ is a linear function of ambient radiation, $V_{\mathrm{oc}}$ shows a logarithmic increase with ambient radiation. Dominant effect caused by the increase in cell temperature is the linear decrease of $V_{\text {oc }}$. Thus, the cell functions less efficiently. $I_{\mathrm{sc}}$ shows only a slight increase with cell temperature.

The effects of the $G$ and cell temperature on characteristics of the cell can be found by equations. $I_{\mathrm{ph}}(A)$ is directly proportional to solar radiation. When solar cell is short-circuited, a negligible current arises in the diode. Thus, a proportional constant short circuit current $I_{\mathrm{sc}}$ related to calculated radiation value (5) is set. Generally panel data are calculated under $G_{\text {ref }}$ on the conditions where sea level, humidity, and aerosol particle density are at average levels. PV cell performance does not change significantly in terms of full sunniness and cloudiness. With the received solar energy, power output shows approximately a linear decrease; however, efficiency rate approximately coincides with the preferred values.

The relationship between photocurrent and temperature is linear (4) and this result is obtained by recording the temperature changes caused by photocurrent differences. The relationship between terminal voltage and current of the cell is given by Shockley equation when there is no radiation on panel cell. When the cell is open-circuited and there is radiation on it, current occurs entirely in the diode. $I-V$ curve is shifted from the origin by the current produced by radiation (3). Saturation current value $I_{0}$ in the temperature of $25^{\circ} \mathrm{C}$ is calculated by open circuit voltage and short circuit current in that temperature (6). Ideality factor is offered as 1.2-1.3 under normal operation conditions and then it is stated that it can be used as initial until a more accurate value is calculated by curve chart simulation. $I_{0}$ has a complicated relationship with temperature; however, it does not include any variables that require evaluation (7). $R_{s}$ on the panel does not have a strong influence on tendency at the $V=V_{\text {oc }}$ point of the $I-V$ curve chart. Equations (8) are found by derivation of (4) and evaluation at the $V=V_{\text {oc }}$ point and by making reformation in terms of $R_{s}$ [34]. 


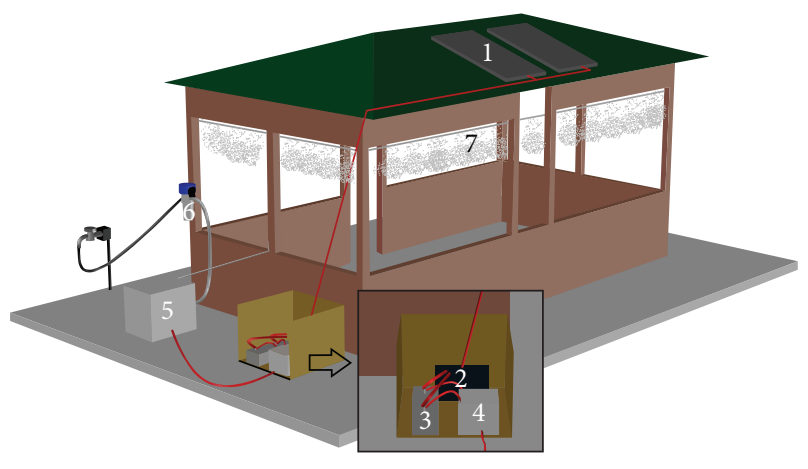
(1) Solar panel
(5) Pump
(2) Charge control
(6) Filter
(3) Battery
(4) Inverter
(7) Mist system

FIGURE 6: Established experimental system.

The main component specifications, characteristics, and prices of the component parts of the photovoltaic misting system are given in Table 3, in which the numbers in parentheses corresponding to these elements are depicted in Figure 6.

\section{The Evaluation of Experimental Study and Photovoltaic Modeling}

In Figures 7, 8, and 9 maximum temperatures $\left({ }^{\circ} \mathrm{C}\right)$ obtained from the thermal camera images, according to the randomly selected $\mathrm{X}$ and $\mathrm{Y}$ coordinates. The location indicated by dark blue color shows the nozzle outlet.

Firstly, the misting system is turned on for $20 \mathrm{~s}$ and turned off for $20 \mathrm{~s}$. In this situation inrush currents induced by pressurized water pump force inverter system. Thus, the system is operated continuously during the experiment.

In Figures 10-12, temperature distribution around the people standing next to misting system is given. As seen from Figure 10, temperature difference between the nozzle outlet and the human body surface is about $12^{\circ} \mathrm{C}$. The location indicated by dark blue color shows the nozzle outlet. In Figures 11 and 12, temperature of people with different positions is given by the thermal camera images.

In order to analyze the performance of the misting system, energy efficiency ratio (EER) and coefficient of performance (COP) are calculated. The EER of a cooling system is the ratio of the output cooling in BTU to the input electrical power consumed by the system in Wh at a given point in time. The COP describes the performance of cooling systems as well as EER. It is commonly used in thermodynamics and given by the following relationship using Carnot cycle [14, 35-37]:

$$
\mathrm{COP}_{\text {carnot }}=\frac{T_{i}}{T_{o}-T_{i}},
$$

where $T_{i}$ and $T_{o}$ are the indoor (arbor area) and outdoor (ambient) temperatures in Kelvin, respectively. The COP is a unitless quantity. The cooling equipment systems used in
TABLE 4: Typical electrical characteristics of BSM-150 PV module.

\begin{tabular}{lcc}
\hline Parameter & Variable & Value \\
\hline Maximum power & $P_{m}$ & $150 \mathrm{~W}$ \\
Power tolerance & $\%$ & +5 \\
Max power voltage & $V_{m}(\mathrm{~V})$ & 18.11 \\
Max power current & $I_{m}(\mathrm{~A})$ & 8.32 \\
Open circuit voltage & $V_{\mathrm{oc}}(\mathrm{V})$ & 22.51 \\
Short circuit current & $I_{\mathrm{sc}}(\mathrm{A})$ & 9.08 \\
Max system voltage & $\mathrm{VDC}$ & 1000 \\
Cell efficiency & $\eta_{c}(\%)$ & $\geq 17$ \\
Cell size & $\mathrm{Mm}$ & $156 \times 156$ \\
$I_{m}$ temperature coefficient & $\left(\% /{ }^{\circ} \mathrm{C}\right)$ & +0.1 \\
$V_{m}$ temperature coefficient & $\left(\% /{ }^{\circ} \mathrm{C}\right)$ & -0.38 \\
$P_{m}$ temperature coefficient & $\left(\% /{ }^{\circ} \mathrm{C}\right)$ & -0.47 \\
$I_{\text {sc }}$ temperature coefficient & $\left(\% /{ }^{\circ} \mathrm{C}\right)$ & +0.1 \\
$V_{\mathrm{oc}}$ temperature coefficient & $\left(\% /{ }^{\circ} \mathrm{C}\right)$ & -0.38 \\
NOCT, nominal operating cell & ${ }^{\circ} \mathrm{C}$ & $48 \pm 2$ \\
temperature & & $\geq 73.3$ \\
Fill factor & $\%$ &
\end{tabular}

The data are based on measurements made in a solar simulator at standard test conditions (STC), which are

(i) illumination of $1 \mathrm{~kW} / \mathrm{m}^{2}$ (1 sun) at spectral distribution of AM 1.5;

(ii) cell temperature of $25^{\circ} \mathrm{C}$ or as otherwise specified (on curves).

residential and small commercial buildings often express cooling system efficiency in terms of the energy efficiency ratio (EER) and/or seasonal energy efficiency ratio (SEER). These coefficients are defined by the cooling effect in Btu (not in tons) divided by the power use in watts (not in $\mathrm{kW}$ ) for the peak day (EER) or the seasonal average day (SEER) [14, 3537]:

$$
\mathrm{EER}_{\text {carnot }}=3.412 \mathrm{COP} \text {, }
$$

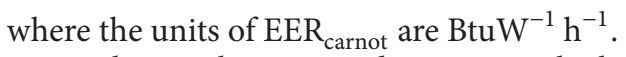

In this work, COP and EER are calculated for the best cooling performance measurement which is displayed in Figure 9. The calculated values of COP and EER are 18.8 and 64.15 , respectively. It is not possible to report SEER in this work due to the fact that the experiments were done over limited time and in summer season. In this study, the ambient temperature was measured at $35^{\circ} \mathrm{C}$. Relative humidity after humidification was measured as an average of $40 \%$. The maximum difference between $T_{i}$ and $T_{o}$ in the conducted experiments is only $15.6^{\circ} \mathrm{C}$. This difference is much lower than typical performance of such misting systems where the difference could be as large as $25^{\circ} \mathrm{C}$ [14].

The Bluesun BSM-150 PV module was chosen for modeling, due to being well suited to traditional applications of photovoltaics. The BSM-150 module provides 150 watt of nominal maximum power and has 36 series connected monocrystalline silicon $(4 \times 9)$ cells. The key specifications are shown in Table 4.

The model of the PV module parameters is evaluated during execution using the equations listed in the previous 

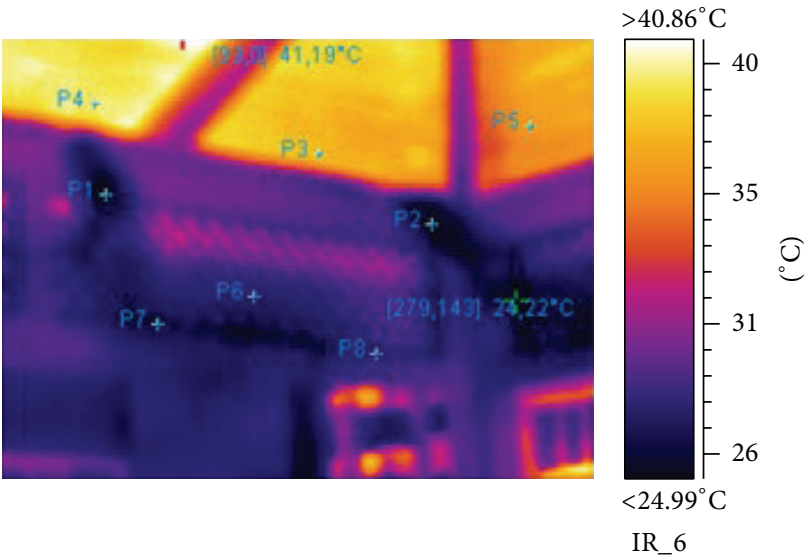

\begin{tabular}{cccccc}
\hline Name & Max temp... & Amb. temp. & Rel. hum. & $X$-pos. & $Y$-pos. \\
\hline IR. & 41.19 & 35 & 40 & & \\
P1 & 25.19 & 35 & 40 & 56 & 84 \\
P2 & 24.79 & 35 & 40 & 232 & 100 \\
P3 & 37.55 & 35 & 40 & 171 & 62 \\
P4 & 39.69 & 35 & 40 & 50 & 35 \\
P5 & 36.18 & 35 & 40 & 285 & 47 \\
P6 & 26.61 & 35 & 40 & 136 & 139 \\
P7 & 25.44 & 35 & 40 & 84 & 154 \\
P8 & 27.27 & 35 & 40 & 202 & 170
\end{tabular}

FIgURE 7: The thermal camera images and information of the arbor subregion, two nozzles.
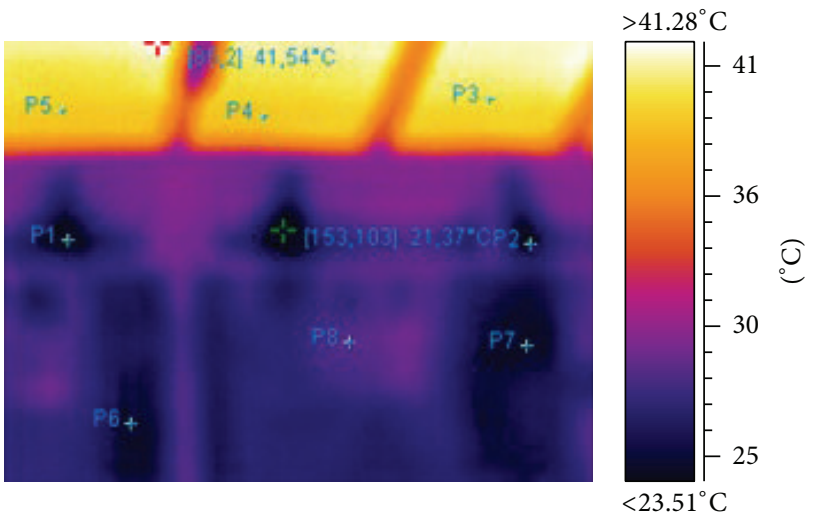

IR_5

\begin{tabular}{cccccc}
\hline Name & Max temp... & Amb. temp. & Rel. hum. & $X$-pos. & $Y$-pos. \\
\hline IR.. & 41.54 & 35 & 40 & & \\
P1 & 22.80 & 35 & 40 & 35 & 107 \\
P2 & 23.71 & 35 & 40 & 285 & 109 \\
P3 & 39.46 & 35 & 40 & 263 & 31 \\
P4 & 38.21 & 35 & 40 & 141 & 40 \\
P5 & 38.40 & 35 & 40 & 32 & 37 \\
P6 & 23.91 & 35 & 40 & 69 & 206 \\
P7 & 23.54 & 35 & 40 & 283 & 164 \\
P8 & 27.79 & 35 & 40 & 187 & 162 \\
\hline
\end{tabular}

FIGURE 8: The thermal camera images and information of the arbor subregion, three nozzles.
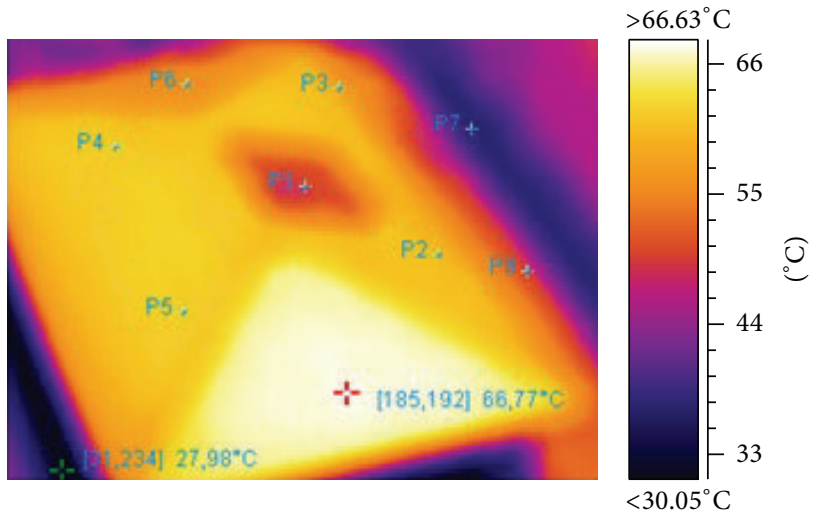

\begin{tabular}{cccccc}
\hline Name & Max temp... & Amb. temp. & Rel. hum. & $X$-pos. & $Y$-pos. \\
\hline IR... & 66.77 & 35 & 40 & & \\
P1 & 47.42 & 35 & 40 & 161 & 79 \\
P2 & 59.62 & 35 & 40 & 233 & 116 \\
P3 & 58.17 & 35 & 40 & 179 & 26 \\
P4 & 61.47 & 35 & 40 & 58 & 58 \\
P5 & 61.53 & 35 & 40 & 95 & 147 \\
P6 & 55.30 & 35 & 40 & 97 & 24 \\
P7 & 34.69 & 35 & 40 & 251 & 48 \\
P8 & 47.66 & 35 & 40 & 281 & 125 \\
\hline
\end{tabular}

IR_7

FIGURE 9: The thermal camera images and information of solar cells on top of arbor.

section. The program calculates the current $I$, using typical electrical parameter of the module $\left(I_{\mathrm{sc}}, V_{\mathrm{oc}}\right)$ and the variables voltage, irradiation $(G)$, and temperature $(T)$.

The program considers the series resistance in the model. This resistance makes the solution for the current $I$ (3) a nonlinear problem, solved using numerical methods. In this program the Newton-Raphson method was used, because the literature indicates much more rapid convergence, for both positive and negative currents.

The output of the Matlab function is shown first for various irradiation levels (Figure 13) and then for various temperatures (Figure 14). 

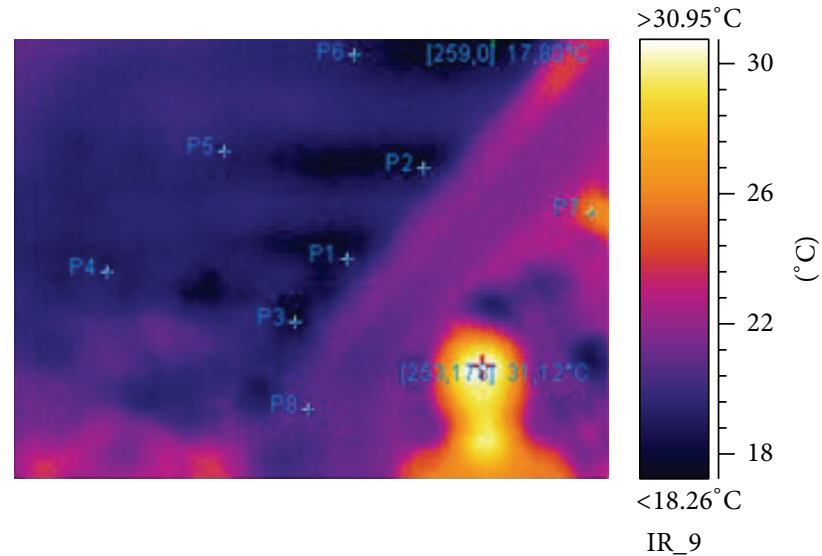

\begin{tabular}{cccccc}
\hline Name & Max temp... & Amb. temp. & Rel. hum. & $X$-pos. & $Y$-pos. \\
\hline IR.. & 31.12 & 35 & 40 & & \\
P1 & 18.80 & 35 & 40 & 179 & 119 \\
P2 & 18.69 & 35 & 40 & 220 & 70 \\
P3 & 18.58 & 35 & 40 & 151 & 153 \\
P4 & 19.23 & 35 & 40 & 50 & 126 \\
P5 & 19.18 & 35 & 40 & 113 & 61 \\
P6 & 18.86 & 35 & 40 & 183 & 9 \\
P7 & 25.74 & 35 & 40 & 310 & 94 \\
P8 & 20.80 & 35 & 40 & 158 & 200 \\
\hline
\end{tabular}

Figure 10: The thermal camera images and information having people under the arbor.
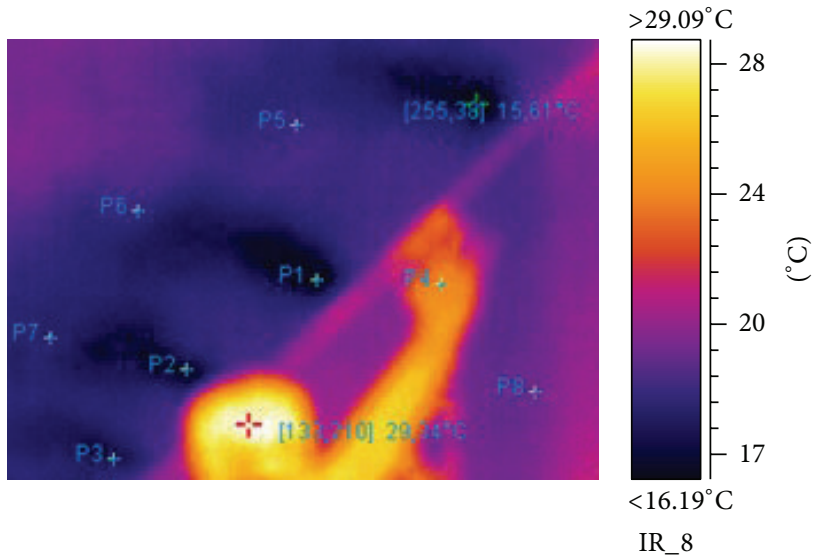

\begin{tabular}{cccccc}
\hline Name & Max temp... & Amb. temp. & Rel. hum. & $X$-pos. & $Y$-pos. \\
\hline IR... & 29.34 & 35 & 40 & & \\
P1 & 15.61 & 35 & 40 & 168 & 131 \\
P2 & 16.39 & 35 & 40 & 98 & 179 \\
P3 & 16.73 & 35 & 40 & 59 & 227 \\
P4 & 24.38 & 35 & 40 & 235 & 133 \\
P5 & 18.27 & 35 & 40 & 157 & 48 \\
P6 & 18.01 & 35 & 40 & 72 & 94 \\
P7 & 17.44 & 35 & 40 & 25 & 162 \\
P8 & 19.67 & 35 & 40 & 285 & 191 \\
\hline
\end{tabular}

FIGURE 11: The thermal camera images and information of people raising one arm.
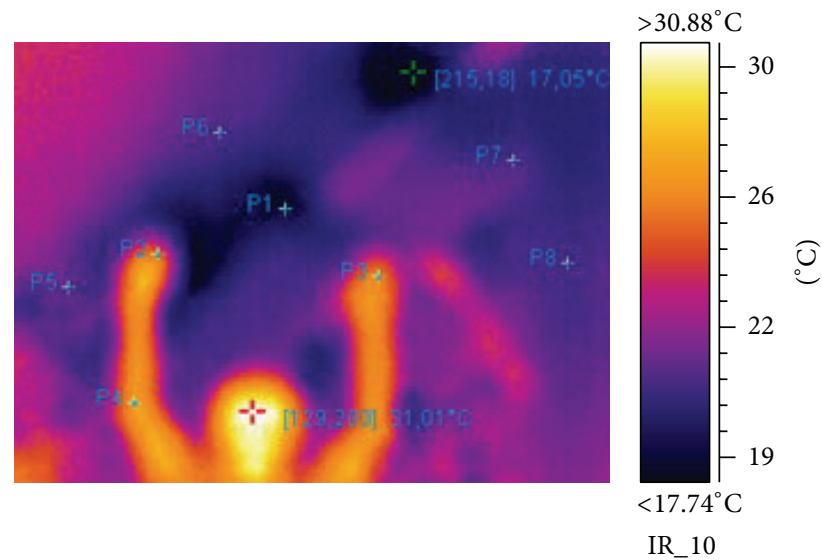

\begin{tabular}{cccccc}
\hline Name & Max temp... & Amb. temp. & Rel. hum. & X-pos. & $Y$-pos. \\
\hline IR.. & 31.01 & 35 & 40 & & \\
P1 & 18.08 & 35 & 40 & 145 & 90 \\
P2 & 24.73 & 35 & 40 & 77 & 114 \\
P3 & 25.70 & 35 & 40 & 195 & 126 \\
P4 & 26.99 & 35 & 40 & 64 & 194 \\
P5 & 20.77 & 35 & 40 & 29 & 132 \\
P6 & 20.48 & 35 & 40 & 110 & 49 \\
P7 & 20.28 & 35 & 40 & 267 & 64 \\
P8 & 20.40 & 35 & 40 & 296 & 119 \\
\hline
\end{tabular}

FIGURE 12: The thermal camera images and information of people raising two arms.

A number of discrete data points are shown on the curves in Figure 14. These are points taken directly from the manufacturer's published curves and show excellent correspondence to the model. For the BSM-150 the curves show that $I_{L}$ changes from 9.08 to $9.35 \mathrm{~A}(\approx 3 \%)$ as $T$ changes from 25 to $75^{\circ} \mathrm{C}$. Figure 15 shows power voltage curves for several temperatures, again the discrete data points taken directly from the manufacturer's published curves, and shows excellent correspondence to the model. 


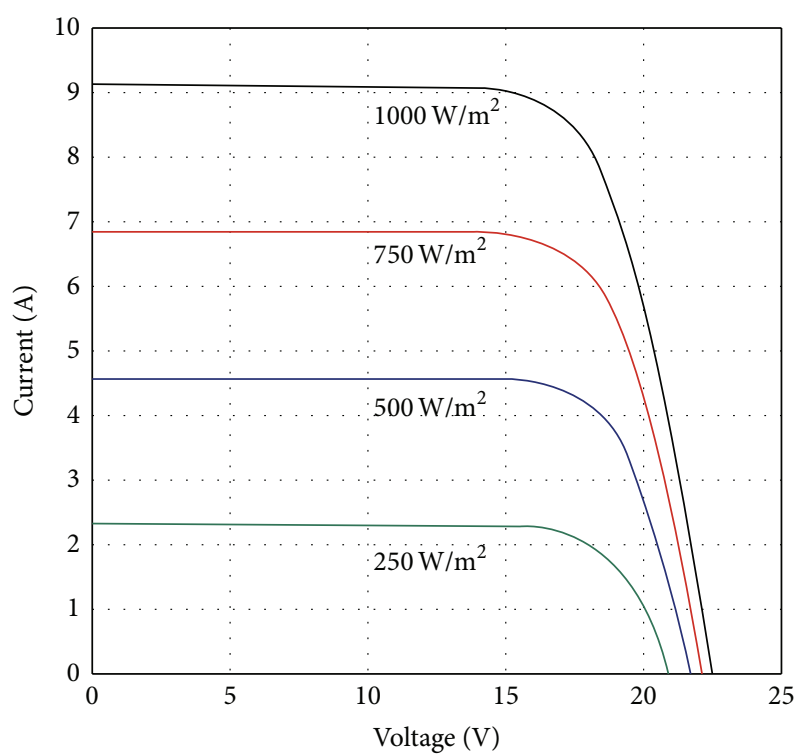

FIGURE 13: Matlab model $I-V$ curves for various irradiation levels $\left(\mathrm{BSM}-150, \mathrm{G}=250,500,750,1000 \mathrm{~W} / \mathrm{m}^{2}, T=25^{\circ} \mathrm{C}\right.$ ).

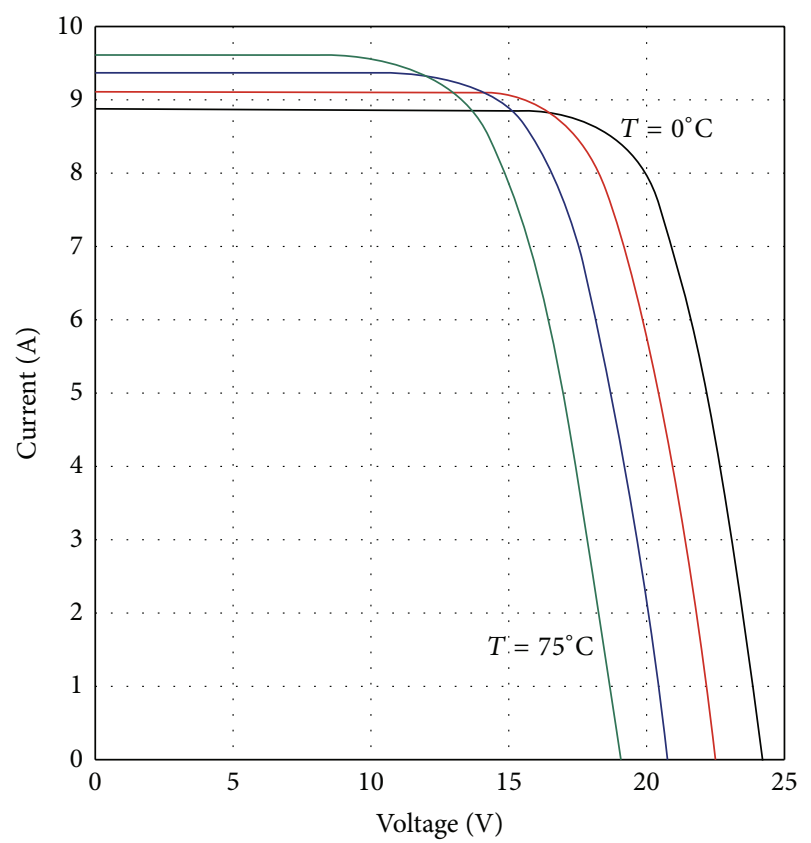

FIgURE 14: Matlab model $I-V$ curves for various temperatures (BSM-150, $G=1000 \mathrm{~W} / \mathrm{m}^{2}, T=0,25,50,75^{\circ} \mathrm{C}$ ).

The cell efficiency and fill factor (FF) of BSM-150 photovoltaic unit are calculated as $17.12 \%$ and 73.71 , respectively (according to the data of Table 4).

\section{Economic Returns to Open Area Investment}

A sufficient economic return on energy efficiency investments is crucial for the sustainable development of the green building industry. The amount spent in establishing system will be recovered after using it for a certain amount of

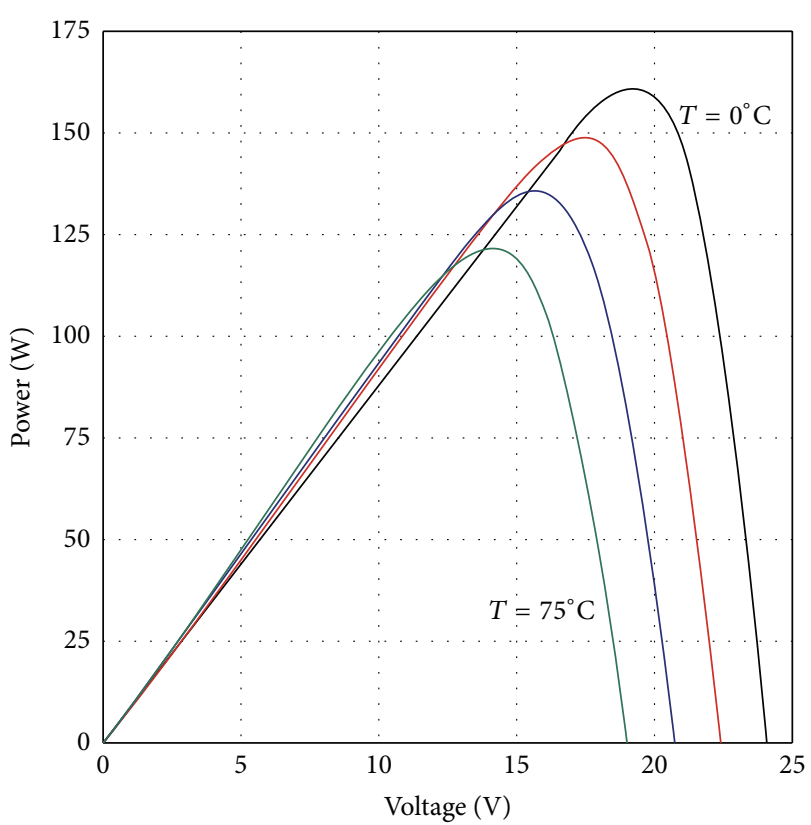

FIgURE 15: Matlab model $P-V$ curves for various temperatures $\left(\mathrm{BSM}-150, G=1000 \mathrm{~W} / \mathrm{m}^{2}, T=0,25,50,75^{\circ} \mathrm{C}\right)$.

time. The return on investment parameter depends on the cost of the parts used in the system and on the cost of operating comparable equipment [14]. In this work, return on investment for solar assisted misting system is compared with the cost of operating an air conditioner that is used to cool a $4 \mathrm{~m} \times 6 \mathrm{~m}$ area. This area is equivalent to the arbor area used by the misting system. The region coefficient of an air conditioner is $308 \mathrm{BTU} / \mathrm{h}$ for Eastern Anatolia $\left(38.6775^{\circ} \mathrm{N}\right.$, $39.1707^{\circ} \mathrm{E}$, Elazig, Turkey). If the account is $24 \mathrm{~m}^{2}$ arbor area is calculated as $24 \times 308=7392 \mathrm{BTU} / \mathrm{h}$. Given that 10 people sit under the arbor for each person $600 \mathrm{BTU} / \mathrm{h}$ is added. Therefore, $10 \times 600=6000 \mathrm{BTU} / \mathrm{h}$ is calculated. Experiments carried out during the day because of lighting effect have been neglected. According to the above assumptions, is calculated as the total cooling load is $13392 \mathrm{BTU} / \mathrm{h}$. The cooling load is $17400 \mathrm{BTU} / \mathrm{h}$ and assessment was made based on the model (Mitsubishi SRK56) [38]. Assume a cost of approximately 1000 Euro for air conditioner, utility cost per $\mathrm{kW}$ of $0.082 \mathrm{Euro} / \mathrm{kW}$, power consumption of air conditioner about $5.09 \mathrm{~kW}(17400 \mathrm{BTU} / \mathrm{h})$, and operating the AC for $8 \mathrm{~h} /$ day for 4 months/year. The cost of misting system is 2480 Euro (see Table 3 ). Thus, the system pays for itself in 3 years and 7 months (3.7 years; payback period) and the cost of operating it afterwards would be free due to the usage of free solar energy.

\section{Conclusions}

Misting system powered up with solar cell is demonstrated for an arbor area. The temperature of arbor was reduced from $35^{\circ} \mathrm{C}$ to $15^{\circ} \mathrm{C}$. Arbor relative humidity values were increased from $20-25 \%$ to $40-50 \%$. When there is no solar energy, electricity from the grid based system operated. 
In this study, cooling was performed using only PV power. As recommended. Solar panels used in the experiments are modeled. An accurate photovoltaic module electrical model is presented and demonstrated in Matlab for a typical $150 \mathrm{~W}$ solar panel. Given solar insolation and temperature, the model returns a current vector for a given voltage vector. The cell efficiency and fill factor (FF) of BSM-150 photovoltaic unit are calculated as $17.12 \%$ and 73.71 , respectively. The return on investment for such a system (misting system powered up with solar cell) is calculated to be 3.7 years. With this system, evaporative cooling example, the initial investment costs and $\mathrm{CO}_{2}$ emissions compared to conventional systems and it is shown that these can be reduced. The misting system can be used in a very large area in order to offer people more comfortable environment.

\section{Nomenclature}

$\begin{array}{ll}A: & \text { Cell area }\left(\mathrm{m}^{2}\right) \\ \mathrm{EC}: & \text { Evaporative cooling } \\ \mathrm{FF}: & \text { Fill factor } \\ G: & \text { Irradiation }\left(\mathrm{W} / \mathrm{m}^{2}\right) \\ n: & \text { Neutron } \\ I: & \text { Current }(\mathrm{A}) \\ I_{\mathrm{ph}}: & \text { Photocurrent }(\mathrm{A}) \\ I_{o}: & \text { Normal diode }(\text { saturation }) \text { current }(\mathrm{A}) \\ I_{m}: & \text { Maximum power current }(\mathrm{A}) \\ I_{\mathrm{oc}}: & \text { Open circuit current }(\mathrm{A}) \\ I_{\mathrm{sc}}: & \text { Short circuit current }(\mathrm{A}) \\ \mathrm{PV}: & \text { Photovoltaic } \\ p: & \text { Proton } \\ P_{m}: & \text { Maximum power }(\text { watt }) \\ R_{s}: & \text { Series resistance }(\Omega) \\ R_{\mathrm{sh}}: & \text { Shunt resistance }(\Omega) \\ T: & \text { Fixed cell temperature }\left({ }^{\circ} \mathrm{C}\right) \\ V: & \text { Voltage }(\mathrm{V}) \\ V_{m}: & \text { Maximum power voltage }(\mathrm{V}) \\ V_{\mathrm{oc}}: & \text { Open circuit voltage }(\mathrm{V}) \\ \mathrm{VDC}: & \text { Maximum system voltage }(\mathrm{V}) . \\ & \end{array}$

\section{Conflict of Interests}

The authors declare that there is no conflict of interests regarding the publication of this paper.

\section{Acknowledgment}

The authors gratefully acknowledge the financial support from the Scientific Research Projects Administration Unit of Firat University for this study performed under projects with grant nos. TEKF 2012/12.04 and TEKF 2012/12.05.

\section{References}

[1] G. A. Giacomelli, "Evaporative cooling system: mist and fog," in Proceedings of the Mississippi Greenhouse Tomato Short Course, Jackson, Miss, USA, March 2003.

[2] 2014, http://en.wikipedia.org/wiki/Evaporative_cooler.
[3] R. Crawford and A. K. Da Silva, "Experimental testing of a passive, evaporation-based roof cooling system," Energy and Buildings, vol. 71, pp. 12-19, 2014.

[4] M. Santamouris and D. Kolokotsa, "Passive cooling dissipation techniques for buildings and other structures: The state of the art," Energy and Buildings, vol. 57, pp. 74-94, 2013.

[5] F. Bruno, "On-site experimental testing of a novel dew point evaporative cooler," Energy and Buildings, vol. 43, no. 12, pp. 3475-3483, 2011.

[6] T. Miyazaki, A. Akisawa, and I. Nikai, "The cooling performance of a building integrated evaporative cooling system driven by solar energy," Energy and Buildings, vol. 43, no. 9, pp. 2211-2218, 2011.

[7] S. T. Smith, V. I. Hanby, and C. Harpham, "A probabilistic analysis of the future potential of evaporative cooling systems in a temperate climate," Energy and Buildings, vol. 43, no. 2-3, pp. 507-516, 2011.

[8] B. Riangvilaikul and S. Kumar, "Numerical study of a novel dew point evaporative cooling system," Energy and Buildings, vol. 42, no. 11, pp. 2241-2250, 2010.

[9] B. Naticchia, M. D’Orazio, A. Carbonari, and I. Persico, "Energy performance evaluation of a novel evaporative cooling technique," Energy and Buildings, vol. 42, no. 10, pp. 1926-1938, 2010.

[10] B. Riangvilaikul and S. Kumar, "An experimental study of a novel dew point evaporative cooling system," Energy and Buildings, vol. 42, no. 5, pp. 637-644, 2010.

[11] J. T. Oliveira, A. Hagishima, and J. Tanimoto, "Estimation of passive cooling efficiency for environmental design in Brazil," Energy and Buildings, vol. 41, no. 8, pp. 809-813, 2009.

[12] H. Montazeri, B. Blocken, and J. L. M. Hensen, "Evaporative cooling by water spray systems: CFD simulation, experimental validation and sensitivity analysis," Building and Environment, vol. 83, pp. 129-141, 2014.

[13] S. Jaber and S. Ajib, "Evaporative cooling as an efficient system in Mediterranean region," Applied Thermal Engineering, vol. 31, no. 14-15, pp. 2590-2596, 2011.

[14] A. Atieh and S. Al Shariff, "Solar energy powering up aerial misting systems for cooling surroundings in Saudi Arabia," Energy Conversion and Management, vol. 65, pp. 670-674, 2013.

[15] N. H. Wong and A. Z. M. Chong, "Performance evaluation of misting fans in hot and humid climate," Building and Environment, vol. 45, no. 12, pp. 2666-2678, 2010.

[16] C. Farnham, M. Nakao, M. Nishioka, M. Nabeshima, and T. Mizuno, "Study of mist-cooling for semi-enclosed spaces in Osaka, Japan," Procedia Environmental Sciences, vol. 4, pp. 228238, 2011.

[17] B. Ford, R. Wilson, M. Gillott, O. Ibraheem, J. Salmeron, and F. J. Sanchez, "Passive downdraught evaporative cooling: performance in a prototype house," Building Research \& Information, vol. 40, no. 3, pp. 290-304, 2012.

[18] N. H. Wong and A. Z. M. Chong, "Performance evaluation of misting fans in hot and humid climate," Building and Environment, vol. 45, no. 12, pp. 2666-2678, 2010.

[19] N. Katsoulas, A. Baille, and C. Kittas, "Effect of misting on transpiration and conductances of a greenhouse rose canopy," Agricultural and Forest Meteorology, vol. 106, no. 3, pp. 233-247, 2001.

[20] L. A. Dombrovsky, V. P. Solovjov, and B. W. Webb, "Attenuation of solar radiation by a water mist from the ultraviolet to the infrared range," Journal of Quantitative Spectroscopy and Radiative Transfer, vol. 112, no. 7, pp. 1182-1190, 2011. 
[21] V. P. Sethi and S. K. Sharma, "Survey of cooling technologies for worldwide agricultural greenhouse applications," Solar Energy, vol. 81, no. 12, pp. 1447-1459, 2007.

[22] D. W. Burger, "Intermittent mist control via solar cells," in Technology and Product Reports, pp. 273-274, Hort Technology, 1994.

[23] Z. Zhang, P.-X. Jiang, Y.-T. Hu, and J. Li, "Experimental investigation of continual-and intermittent-spray cooling," Experimental Heat Transfer, vol. 26, no. 5, pp. 453-469, 2013.

[24] U. Eicker, A. Colmenar-Santos, L. Teran, M. Cotrado, and D. Borge-Diez, "Economic evaluation of solar thermal and photovoltaic cooling systems through simulation in different climatic conditions: an analysis in three different cities in Europe," Energy and Buildings, vol. 70, pp. 207-223, 2014.

[25] G. Ban-Weiss, C. Wray, W. Delp, P. Ly, H. Akbari, and R. Levinson, "Electricity production and cooling energy savings from installation of a building-integrated photovoltaic roof on an office building," Energy and Buildings, vol. 56, pp. 210-220, 2013.

[26] http://www.mgm.gov.tr/en-US/forecast-cities.aspx?m= ELAZIG.

[27] http://www.rapidcool.com/blog/benefits-of-misting-systems/.

[28] Information about solar cells, 2014, http://en.wikipedia.org/ wiki/Photovoltaics.

[29] F. M. Gonzalez-Longatt, "Model of photovoltaic module in Matlab," in II Congreso Iberoamericano de Estudiantes de Ingeniería Eléctrica Eléctrica, Electrónica y Computación (II CIBELEC '05), 2005.

[30] A. Hansen, P. Lars, H. Hansen, and H. Bindner, Models for a Stand-Alone PV System, Risø National Laboratory, Roskilde, Denmark, 2000, http://www.risoe.dk/rispubl/solenergi/sec-r12.pdf.

[31] G. Walker, "Evaluating MPPT converter topologies using a MATLAB PV model," Journal of Electrical \& Electronics Engineering, vol. 21, pp. 49-56, 2001.

[32] E. Lorenzo, Solar Electricity Engineering of Photovoltaic Systems, Artes Gráficas Gala S.L., Madrid, Spain, 1994.

[33] CIGRE TF38.01.10, Modeling New Forms of Generation and Storage, 2000.

[34] J. A. Gow and C. D. Manning, "Development of a photovoltaic array model for use in power-electronics simulation studies," IEE Proceedings on Electric Power Applications, vol. 146, no. 2, pp. 193-200, 1999.

[35] Y. A. Çengel and M. A. Boles, Thermodynamics: An Engineering Approach, McGraw-Hill, 7th edition, 2011.

[36] The Engineering Tool Box, 2014, http://www.engineeringtoolbox.com/.

[37] Glossary of Efficiency Terms, 2014, http://www.csgrp.com/ homeowners-renters/home-energy-efficiency-tips-energyinfo/glossary/.

[38] Calculations about the air conditioning, 2014, http://www .iklimplus.com.tr/klimalar-hakkinda/klima-hesabi.html. 

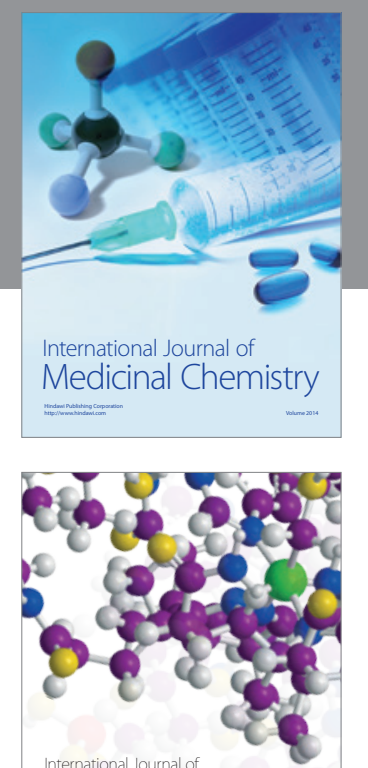

\section{Carbohydrate} Chemistry

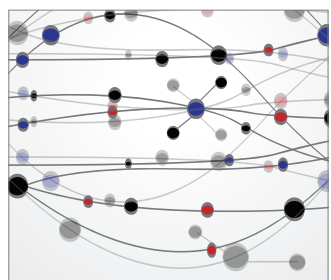

The Scientific World Journal
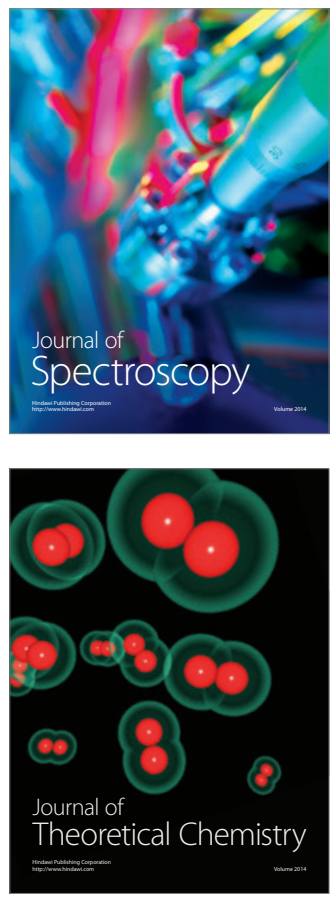
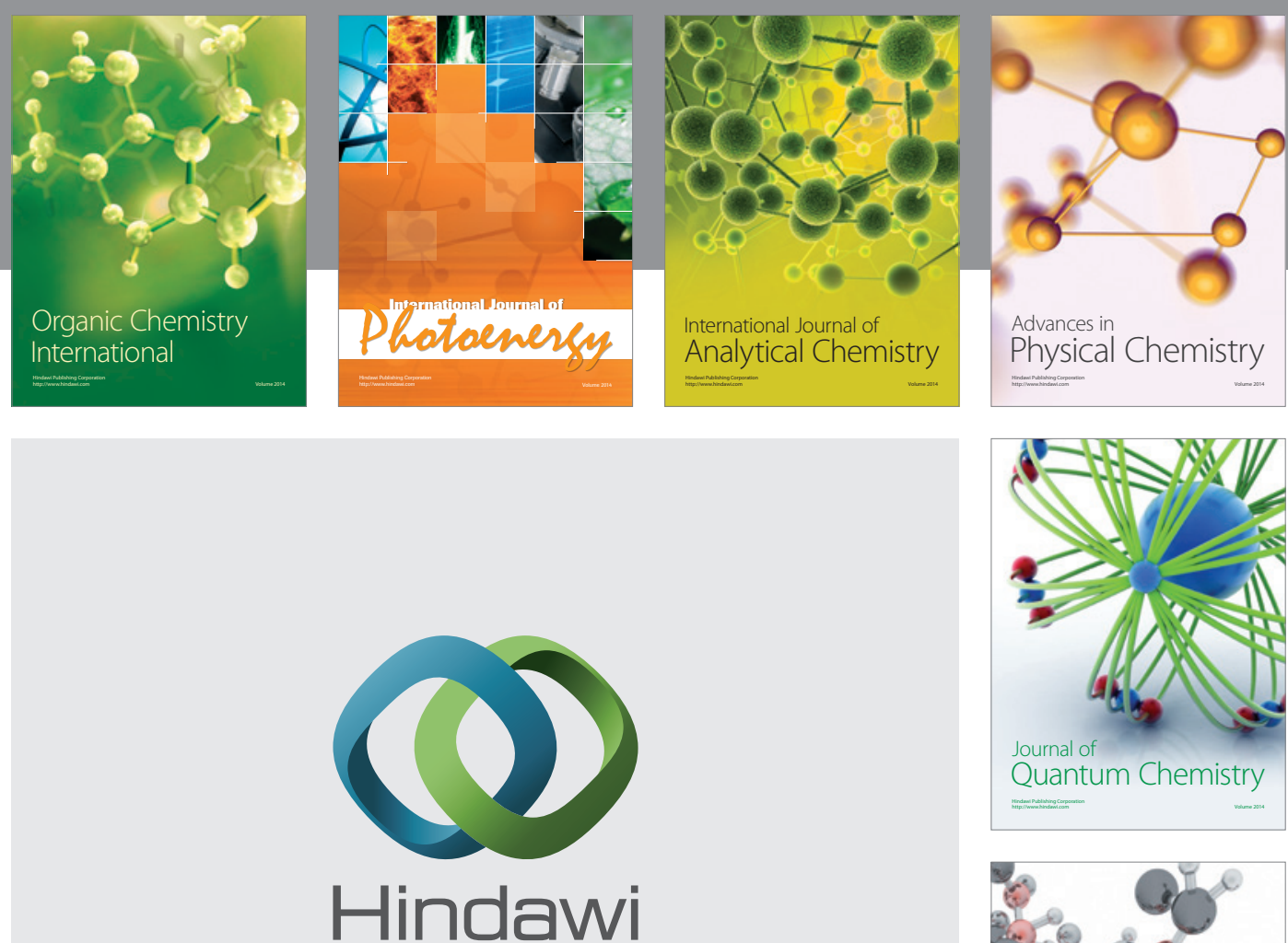

Submit your manuscripts at

http://www.hindawi.com

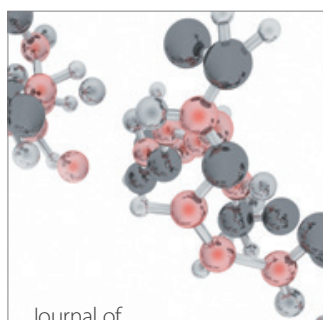

Analytical Methods

in Chemistry

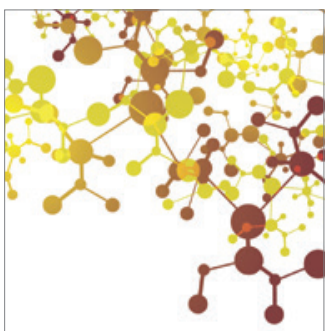

Journal of

Applied Chemistry

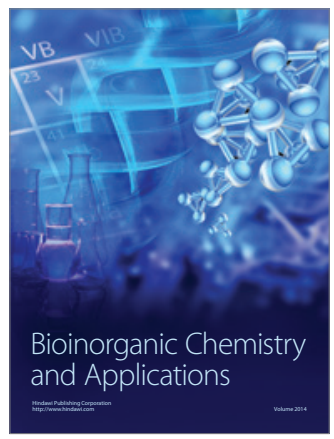

Inorganic Chemistry
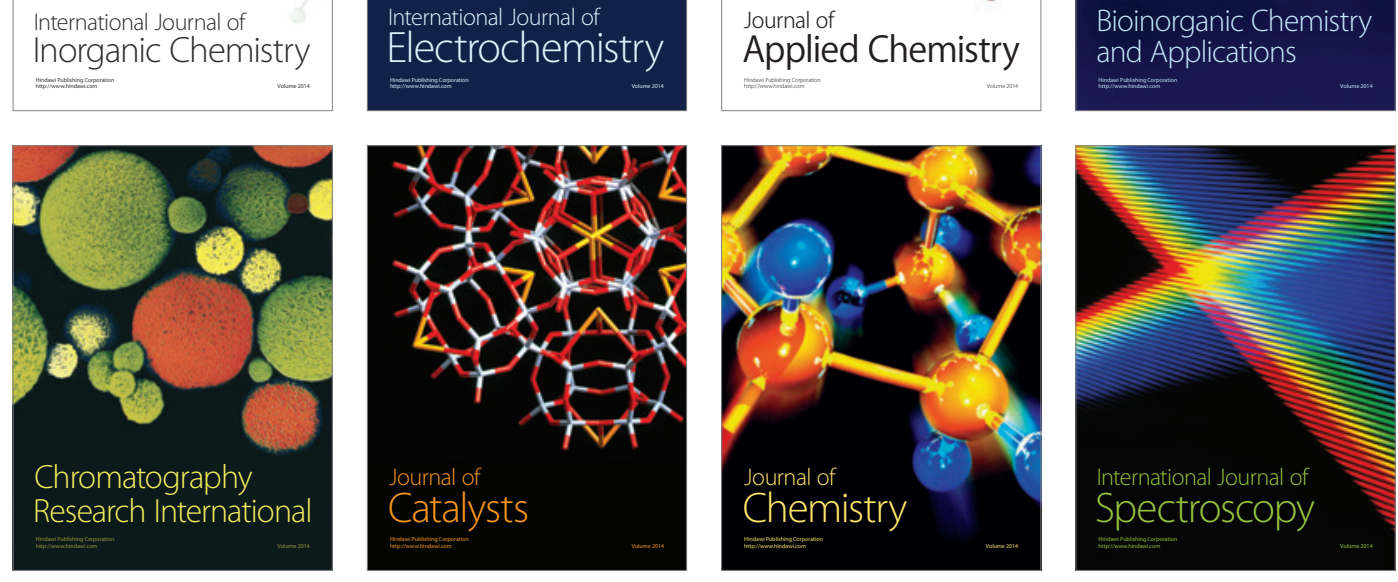